\title{
POTRET PENYEMBELIHAN HEWAN QURBAN PADA ERA NEW NORMAL DI KABUPATEN KOTAWARINGIN BARAT
}

\section{Portrait of Animal Qurban Slaughter in the New Normal Era In Kotawaringin Barat Regency}

\author{
Ayutha Wijinindyah ${ }^{1}$ \\ 1Universitas Antakusuma \\ Email: aaayutha@gmail.com
}

\begin{abstract}
ABSTRAK
Penyembelihan hewan qurban adalah salah satu bentuk ibadah umat muslim. Pada situasi pandemi saat ini maka perlu diperhatikan prosedur penyembelihan hewan qurban sehingga pelaksanaannya sesuai dengan protokol kesehatan. Penelitian ini bertujuan untuk mengidentifikasi pelaksanaan penyembelihan hewan qurban yang sesuai dengan syariat Islam dan protokol kesehatan terkait Covid-19. Penelitian ini adalah penelitian deskriptif dengan metode survei yang dilakukan pada tempat pemotongan hewan yang ada di Kabupaten Kotawaringin Barat, Kalimantan Tengah. Hasil memperlihatkan protokol kesehatan sudah dapat diterapkan antara lain terdapat perbedaan petugas yang menangani penanganan daging dan jeroan, penyediaan fasilitas cuci tangan (sabun atau handsanitizer), menghindari kontak langsung dan memperhatikan etika bersin dan batuk atau meludah, panitia juga berasal dari lingkungan tempat tinggal yang sama dan tidak dalam masa karantina mandiri, melakukan pembersihan setelah kegiatan selesai. Kesimpulannya, petugas secara umum mengetahui protokol kesehatan, namun protokol kesehatan belum diterapkan pada saat penyembelihan hewan qurban. Edukasi dari dinas terkait memberi pengaruh bagi masyarakat tentang protokol kesehatan selama penyembelihan hewan qurban.
\end{abstract}

Kata kunci: Hewan Kurban, Kenormalan Baru, Penyembelihan, Protokol Kesehatan

\begin{abstract}
The slaughter of qurban animals in the days of Idul Al-Adha that called qurban, is the one form of Muslim worship. In the current pandemic situation, it is necessary for pay attention to the implementations of slaughtering procedures accordance with health protocols. The aim of this research is to identify that sacrificial animal slaughter aligned with Islamic law and implementation of helath protocol of Covid19. This research is a descriptive study with a survey method conducted at the slaughterhouse in Kotawaringin Barat Regency, Kalimantan Tengah. The results showed that health protocols can be applied namely there are differences in officers who handled meat and offal handling, providing hand washing facilities (soap or handsanitizer), avoiding direct contact and paying attention to the ethics of sneezing and coughing or spitting, the committee also comes from the same residential environment and not in self-quarantine period, cleaning up after the activity completely. In conclusion, officers generally know health protocols, but health protocols have not been applied at the time of slaughtering qurban animals. Education from related agencies has an impact on the community about health protocols during sacrificial animal slaughter.
\end{abstract}

Keywords: Qurban Animals, New Normal, Slaughter, Health Protocol

\section{PENDAHULUAN}

Islam merupakan agama yang dianut mayoritas masyarakat di Indonesia. Jumlah penduduk Indonesia hingga tahun 2019 diperkirakan 87,2\% (207.200.000) penduduknya menganut agama 
Islam. Bahkan di tingkat dunia, beberapa media mengklaim jumlah penganut Islam di Indonesia adalah terbesar di dunia (Syafii, 2019). Salah satu hari raya umat Islam adalah hari raya Idul Adha atau dikenal dengan nama hari raya Qurban. Penyembelihan hewan Qurban dalam Islam sebagai ritual dan peribadatan telah dilakukan selama ribuan tahun. Dalam kamus besar Bahasa Indonesia, kata Qurban berarti mempersembahkan kepada Tuhan. Qurban dalam bahasa Indonesia berasal dari terjemahan bahasa Arab yaitu qaraba yang berarti dekat. Ibadah Qurban adalah ibadah dimana yang dikurbankan adalah binatang tertentu (antara lain unta, sapi, kerbau, biri-biri, domba, kambing) yang waktu pelaksanaannya pada hari raya Idul Adha dan hari Tasyrik (yakni tiga hari berikutnya yaitu 11, 12 dan 13 Dzulhijjah) dengan tujuan mendekatkan diri kepada Allah SWT (Jayusman, 2012). Ibadah Qurban dalam Islam merupakan bentuk pengabdian kepada Allah SWT yang merupakan manifestasi dari iman, yakni rasa syukur atas nikmat yang ada (Sabiq, 1983).

Pandemi Coronavirus atau Covid-19 merupakan penyakit menular yang disebabkan oleh sindrom pernapasan akut coronavirus 2 (Sars-CoV-2) dengan gejala umum termasuk demam, batuk, dan sesak nafas. Kasus Covid-19 terjadi di dunia hingga September 2020 tercatat 26.600.000 juta dan 919.000 ribu meninggal. Berdasarkan data dari Covid19.go.id, kasus Covid-19 telah mencapai 221.523 kasus, dengan angka kematian 8.841 orang dan pasien yang sembuh mencapai 150.045. Kasus di Indonesia adalah tingkat kematian yang tinggi di Asia Pasifik dan Asia Tenggara (Tribunnewsmaker, 2020). World Health Organization (WHO) menetapkan status pandemik global Covid-19 setelah virus berbahaya ini menyebar ke sebagian besar wilayah dunia. Bahkan pengumpulan massa dalam jumlah besar telah dihindari untuk menghindari proses penularan. Banyak manusia terinfeksi dari hewan asal atau hasil dari penularan antarspesies.

Covid-19 secara luas ada pada hewan sebagai inang (host) (Cui et al., 2019; Su et al., 2016), sehingga sangat penting untuk menjaga kesehatan hewan ternak, karena menjadi salah satu isu pada peternakan hewan (Decaro \& Lorusso, 2020). Pada tanggal 28 Mei 2020 pemerintah pusat melalui Menteri Perencanaan Pembangunan Nasional menyampaikan Protokol Masyarakat Produktif dan Aman Covid-19 menuju Normal Baru (New Normal), yakni masyarakat diharapkan mampu beradaptasi dan hidup berdampingan dengan Covid-19. Pemerintah menyebutnya dengan 'Penyesuaian PSBB' (Muhyiddin, 2020). Adanya ritual kegiatan pada Idul Adha, yakni penyembelihan hewan Qurban menimbulkan banyak polemik terkait pandemi akibat Covid-19. Berdasarkan latar belakang di atas, maka dilakukan penelitian dengan tujuan untuk mengetahui potret penyembelihan hewan Qurban di era new normal yang ada di Kabupateng Kotawaringin Barat, Kalimantan Tengah.

\section{METODE}

Penelitian ini merupakan penelitian deskriptif dengan metode survei menggunakan kuesioner yang dilakukan pada tempat dilakukannya penyembelihan hewan Qurban. Lokasi survei dilakukan pada 13 tempat yang berbeda tersebar di beberapa kecamatan di Kabupaten Kotawaringin Barat, Kalimantan Tengah.

\section{HASIL DAN PEMBAHASAN}

Hingga saat ini belum ditemukan penelitian tentang adanya penyebaran Covid-19 melalui makanan yang dapat menyebabkan kematian meskipun tidak ada informasi secara mendetail bahwa Covid-19 ada di bahan pangan. World Healt Organization (WHO) merekomendasikan penerapan higienitas yang baik selama penanganan bahan pangan, penyiapan misalnya mencuci bahan, memasak bahan agar menhindari potenisal kontaminasi langsung antara bahan pangan yang sudah dimasak dan belum dimasak (EFSA, 2020). Adanya masa new normal akibat adanya Covid-19 ini 
membuat pelaksanaan penyembelihan hewan Qurban nampak berbeda pada tahun ini karena sejumlah aturan harus diterapkan. Pengetahuan serta praktik penerapan didapat dari banyak sumber. Sosial media memegang peranan penting sehingga masyarakat lebih berhati-hati terhadap kesehatan dan penerapan adaptasi terkait higienitas pada masa pandemi ini (ANR, 2020). Hal ini seperti dikemukakan oleh Dyal et al. (2020) bahwa tantangan sosialkultutral pada masa Covid-19 di industri daging dan unggas salah satunya adalah mengkomunikasikan kepada para pekerja dengan latar belakang yang berbeda, terkait edukasi dan pelatihan pekerja untuk keamanan dan kesehatan.

Tabel 1. Potret Penyembelihan Hewan Qurban di Kabupaten Kotawaringin Barat

\begin{tabular}{|c|c|c|c|}
\hline No. & Pertanyaan & Ya & Tidak \\
\hline 1 & $\begin{array}{l}\text { Pemotongan hewan kurban dilakukan di fasilitas pemotongan hewan } \\
\text { kurban yang telah mendapat izin dari pemerintah daerah kabupaten } \\
\text { atau kota setempat yang membidangi fungsi kesehatan masyarakat } \\
\text { veteriner }\end{array}$ & $69,23 \%$ & $30,77 \%$ \\
\hline 2 & $\begin{array}{l}\text { Panitia juga berasal dari lingkungan tempat tinggal yang sama dan } \\
\text { tidak dalam masa karantina mandiri }\end{array}$ & $100,00 \%$ & $0,00 \%$ \\
\hline 3 & $\begin{array}{l}\text { Melakukan pengukuran suhu tubuh di tiap pintu masuk tempat } \\
\text { pemotongan }\end{array}$ & $15,38 \%$ & $84,62 \%$ \\
\hline 4 & $\begin{array}{l}\text { Tiap orang yang memiliki gejala demam atau nyeri tenggorokan } \\
\text { atau batuk, pilek atau sesak nafas, dilarang masuk ke tempat } \\
\text { pemotongan }\end{array}$ & $92,31 \%$ & $7,69 \%$ \\
\hline 5 & $\begin{array}{l}\text { Terdapat petugas yang berada di area penyembelihan dan } \\
\text { penanganan daging dan jeroan }\end{array}$ & $100,00 \%$ & $0,00 \%$ \\
\hline 6 & $\begin{array}{l}\text { Ada edukasi dari petugas penanggungjawab kegiatan kurban, yakni } \\
\text { mengedukasi setiap orang untuk menghindari atau menyentuh } \\
\text { bagian muka (termasuk mata, hidung, telinga dan mulut) }\end{array}$ & $76,92 \%$ & $23,08 \%$ \\
\hline 7 & Setiap orang menggunakan alat pelindung & $61,54 \%$ & $38,46 \%$ \\
\hline 8 & $\begin{array}{l}\text { Petugas memakai masker, faceshield, sarung tangan sekali pakai, } \\
\text { aapron, dan penutup kaki atau sepatu (pilih salah satu) }\end{array}$ & $92,31 \%$ & $7,69 \%$ \\
\hline 9 & $\begin{array}{l}\text { Penanggung jawab kegiatan kurban menyediakan fasilitas cuci } \\
\text { tangan menggunakan sabun ataupung fasilitas handsanitiser }\end{array}$ & $100,00 \%$ & $0,00 \%$ \\
\hline 10 & $\begin{array}{l}\text { Setiap orang menghindari berjabat tangan atau kontak langsung } \\
\text { serta memperhatikan etika batuk, bersin dan meludah }\end{array}$ & $100,00 \%$ & $0,00 \%$ \\
\hline 11 & $\begin{array}{l}\text { Petugas memmbawa peralatan sendiri atau tidak melakukan saling } \\
\text { peminjaman alat }\end{array}$ & $92,31 \%$ & $7,69 \%$ \\
\hline 12 & $\begin{array}{l}\text { Terdapat tata cara untuk mengatur kepadatan dengan membatasi } \\
\text { jumlah panitia dalam pelaksanaan pemotongan hewan kurban }\end{array}$ & $76,92 \%$ & $23,08 \%$ \\
\hline 13 & $\begin{array}{l}\text { Terdapat perlakuan pembatasan di fasilitas pemotonga hewan } \\
\text { kurban yang hanya dihadiri oleh panitia }\end{array}$ & $76,92 \%$ & $23,08 \%$ \\
\hline 14 & Terdapat pengaturan jarak minimal 1 meter & $69,23 \%$ & $30,77 \%$ \\
\hline 15 & $\begin{array}{l}\text { Tidak saling berhadapan antar petugas saat melakukan aktivitas } \\
\text { pengulitan, pencacahan, penanganan dan pengemasan daging }\end{array}$ & $76,92 \%$ & $23,08 \%$ \\
\hline 16 & $\begin{array}{l}\text { Setiap orang melakukan pembersihan tempat pemotongan hewan } \\
\text { dan peralatan yang akan maupun yang telah digunakan serta } \\
\text { membuang kotoran atau limbah pada fasilitas penanganan kotoran } \\
\text { atau limbah }\end{array}$ & $100,00 \%$ & $0,00 \%$ \\
\hline
\end{tabular}




\begin{tabular}{|c|c|c|c|}
\hline No. & Pertanyaan & Ya & Tidak \\
\hline 17 & $\begin{array}{l}\text { Setiap orang di tempat pemotongan membersihkan diri sebelum } \\
\text { melakukan kontak dengan keluarga di rumah }\end{array}$ & $84,62 \%$ & $15,38 \%$ \\
\hline 18 & $\begin{array}{l}\text { Pendistribusian daging kurban dilakukan oleh panitia ke rumah } \\
\text { mustahik }\end{array}$ & $84,62 \%$ & $15,38 \%$ \\
\hline 19 & Petugas mengetahui protokol penyembelihan di era new normal & $84,62 \%$ & $15,38 \%$ \\
\hline 20 & $\begin{array}{l}\text { Petugas pernah mendapat edukasi atau penyuluhan dari dinas } \\
\text { terkait tata cara pemotongan hewan qurban di era new normal }\end{array}$ & $84,62 \%$ & $15,38 \%$ \\
\hline
\end{tabular}

Hasil penelitian memperlihatkan bahawa 69,23\% pemotongan hewan Qurban dilakukan setelah mendapat izin dari pemerintah setempat, dan sisanya yakni 30,77\% tidak melakukan permohonan izin. Pemotongan hewan Qurban sebaiknya dilakukan dengan izin pemerintah. Kementerian Pertanian menyarankan agar panitia Qurban mengajukan izin kepada pemerintah daerah jika penyembelihan dilakukan di luar rumah potong hewan (RPH). Opsi terbaik bagi penyembelihan di tengah pandemic adalah menyembelih hewan Qurban di rumah potong hewan (RPH) khususnya yang berada di zona merah Covid-19, namun jika tidak memungkinkan maka pelaksanaan Qurban bisa dilakukan secara mandiri, yakni panitia Qurban harus mengajukan izin ke pemerintah daerah setempat. Tim dari dinas akan memeriksa hewan Qurban tersebut, yakni kondisi hewan Qurban yang dibuktikan dengan surat keterangan kesehatan hewan. Hal ini mengacu pada Surat Edaran (SE) Nomor 0008/SE/PK.320/F/06/2020 tentang Pelaksanaan Kegiatan Kurban dalam Situasi Wabah Bencana Nonalam Covid-19, serta Surat Edaran Bupati Kotawaringin Barat No 800/765/PKH.3 tentang Pedoman Pelaksanaan Kegiatan Kurban Dalam Situasi Wabah Bencana Non Alam Corona Virus Diseaeae (Covid-19) di Wilayah Kabupaten Kotawaringin Barat.

Penyembelihan Qurban di Kotawaringin Barat bisa dilakukan di masjid atau tempat lain yang memungkinkan. Scara formal biasanya terdapat pendaftaran melalui takmir masjid, namun karena belum meluasnya informasi terkait perubahan protokol penyembelihan hewan Qurban di masa pandemic ini, maka ada beberapa lokasi yang tidak terdata oleh Dinas terkait. Dinas Peternakan dan Kesehatan Hewan di Kotawraingin Barat dalam hal ini hanya mampu mengawasi titik-titik lokasiyang sudah terdata, baik melalui PPL maupun Kemenag. Keterbatasan yang ada membuat belum semua lokasi penyembelihan bisa diawasi. Hal ini yang membuat 30,77\% pelaksanaan hewan Qurban dilaksanakan tanpa terlebih dahulu melalui perizinnan pemerintah setempat.

Sebanyak $100 \%$ lokasi penyembelihan menyatakan bahwa panitia yang ada pada kegiatan penyembelihan hewan Qurban berasal dari lingkungan tempat tinggal yang sama dengan lokasi penyembelihan, serta dipastikan tidak sedang dalam masa karantina mandiri. Kebijakan karantina dan isolasi khusus dilakukan sebagai langkah pengobatan dengan pantauan ketat. Selama isolasi diberikan petugas medis yang mampu memberikan pengobatan tepat terhadap penderita, dan petugas isolasi tersebut diberikan pengamanan khusus agar tidak ikut tertular. Pemerintah setempat memberikan pasokan bahan makanan kepada masyarakat yang tertular (Mukharom, 2020). Hal ini dikarenakan potensial terjadi penularan pada makanan akibat dari pekerja, dan sektor pertanian serta peternakan menjadi sumber kontaminasi untuk bahan pangan atau kontak pada permukaan. Produksi bahan pangan atau pemrosesan yang dikelola dengan melibatkan banyak orang dapat menyebabkan kontaminasi secara langsung pada sumber pertanian dan peternakan hingga ke meja makan (Randazzo et al., 2020),

Screening procedures seperti pengecekan suhu tubuh, adalah salah satu tindakan awal untuk mencegah adanya penularan Covi-19 ke orang lain (Dyal et al., 2020). Pada penelitian terlihat masih sedikit tempat penyembelihan hewan Qurban yang melakukan pengecekan suhu tubuh sebelum petugas beraktifitas, yakni 15,38\% melakukan pengukuran suhu tubuh di tiap pintu masuk tempat 
pemotongan, sedang sisanya yakni $84,62 \%$ belum melakukan pengcekan suhu tubuh. Pengecekan suhu tubuh adalah indikasi awal, dikarenakan salah satu gejala terinfeksi Covid-19 adalah terdapatnya gejala demam, yang berarti terjadi kenaikan suhu tubuh. Tidak dilakukannya pengecekan suhu tubuh setiap petugas juga dikarenakan keterbatasan alat pengukur suhu tubuh; namun secara mandiri sebanyak 92,31\% tempat lokasi penyembelihan memperlihatkan bahwa apabila setiap orang yang memiliki gejala Covid-19 seperti gejala demam, nyeri tenggorokan, batuk, pilek, atau sesak nafas, maka dilarang masuk ke rempat pemotongan. Adapun sisanya yakni 7,69\% cenderung mengabaikan gejala Covid-19, sehingga tanpa ada pengecekan terlebih dahulu memperbolehkan setiap petugas untuk melakukan kegiatan penyembelihan.

Pada penanganan hewan Qurban telah 100\% dilakukan pembagian tugas yakni antara area penyembelihan dan tempat penanganan daging dan jeroan. Seperti telah diketahui bahwa Covid-19 bersifat zoonis, yang artinya dapat ditularkan dari hewan kepada manusia. Hal itu dapat terjadi jika hewan terinfeksi disembelih untuk dikonsumsi (Yuan et al.,2020). Virus corona telah teridentifikasi bisa terdapat pada kelelawar, binatang ternak, tikus, ayam, kalkun, babi, anjing, kelinci, kuda, dan dapat menyebabkan gangguan pernafasan serta penyakit gangguan lambung (Dhama et al., 2019; Monchatre et al., 2017; Dhama et al., 2014).

SARAS-CoV-2 adalah jenis baru dan virus ini positif ada pada lapisan lemak, dan hampir $70 \%$ genomnya berada pada permukaan sel yang mengandung protein (Yuan et al., 2020). Meskipun secara penelitian belum teridentifikasi bahwa terdapat hubungan antara produk pangan dengan SARS-CoV-2, namun mengacu pada FDA, konsumsi daging atau organ bagian dalam hewan dapat menyebabkan zoonotic foodborne infections. Sehingga, penting adanya pembagian petugas antara area penyembelian dengan penanganan daging dan jeroan, tidak dijadikan dalam satu area dengan petugas yang sama. Meskipun secara teori, adanya kontak pada permukaan yang terkontaminasi oleh seseorang yang telah terkontaminasi, menyebabkan bahan makanan secara tidak langsung terkena kontaminasi ketika disentuh pada berbagai kegiatan: memotong daging, mencincang daging, membersihkan, hingga tahap memasak yang tidak sempurna (European Commision, 2020). Pemisahan petugas pada saat menyembelih dan memotong bagian-bagian pada hewan Qurban adalah salah satu hal yang perlu juga diperhatikan. Penanganan yang tidak tepat dapat menyebabkan kontaminasi secara langsung dan dapat dengan mudah menyebarkan virus.

Hasil memperlihatkan bahwa 61,54\% petugas menggunakan pelindung, dan 38, 46\% tidak menggunakan pelindung; sebanyak 92,31\% alat pelindung yang digunakan bermacam-macam antara lain masker, faceshield, sarung tangan sekali pakai, penutup kaki (sepatu), sementara 7,69\% petugas tidak menggunakan alat pelindung yang tertera. Secara umum, alat pelindung yang digunakan adalah masker. Hal ini terlihat dari hasil sebanyak 76,92\% telah ada edukasi dari petugas penanggung jawab kegiatan Qurban yakni mengedukasi setiap orang untuk menghindari atau menyentuh bagian muka (termasuk mata, hidung, telingda dan mulut), sedang sisanya 23,08\% petugas penanggungjawab kegiatan Qurban tidak melakukan tahapan edukasi terkait protokol kesehatan pada penyembelihan hewan Qurban di era new normal. Penting bagi petugas untuk memahami protokol kesehatan seperti mencegah menyentuh sekitar wajah dengan tangan, mencegah kontak dengan orang dalam jumlah banyak (WHO, 2020). Pengontrolan higienitasi digunakan untuk mencegah kontaminasi bahan pangan (daging) dari mikroba pathogen serta bertujuan menjaga kontaminasi makanan dari kemungkinan virus Covid-19.

Tahapan higienitasi antara lain dari penyemprotan disinfektan pada fasilitas dan peralatan, menjaga kontaminasi langsung antara bahan pangan, penerapan higinitasi secara personal (seperti mencuci tangan dengan sabun atau menggunakan disinfektan, memakan sarung tangan, maksker, face cover, memperhatikan kebersihan pakaian dan sepatu). Proses edukasi di dalamnya juga menyangkut protokol bahwa setiap orang menghindari kontak langsung, memperhatikan etika 
batuk, bersin dan meludah (100\%). Hal ini termasuk bagian dari menghilangkan kebiasaan yang tidak higienis seperti bersin dan batuk di sembarang tempat (Government of Ireland, 2020; IACP, 2020, Wei et al., 2020). Penggunaan alcohol-based pada hand sanitizer sangat direkomendasikan oleh Department of Agriculture for food safety di Amerik Serikat, karena mungkin dapat terjadi penularan Covis-19 akibat proses pengolahan daging dan unggas yang terjadi kontak fisik dengan petugas (Dyal et al., 2020). Hal ini terlihat dari hasil yakni $100 \%$ penanggung jawab kegiatan Qurban menyediakan fasilitas cuci tangan dengan menggunakan sabun atau pun fasilitas handsanitiser.

Pada penyembelihan Qurban, sebanyak 76,92\% telah terdapat tata cara untuk mengatur kepadatan dengan membatasi jumlah panitia dalam pelaksanaan pemotongan hewan serta nilai yang sama pada pembatasan fasilitas pemotongan hewan Qurban yang hanya dihadiri oleh panitia, ternyata pada hasil memperlihatkan bahwa 23,08\% masih ada lokasi pemotongan hewan Qurban yang tidak melaksanakan pengaturan kepadatan dengan membatasi jumlah panitia dalam pelaksanaan pemotongan hewan Qurban dan perlakuan pembatasan bahwa pemotongan hewan Qurban hanya dihadiri oleh Panitia. Hal ini mengindikasikan bahwa beberapa lokasi penyembelihan belum mampu menerapkan standar protokol penyembelihan hewan Qurban di era new normal berdasarkan Surat Edaran Bupati Kotawaringin Barat No 800/765/PKH.3, karena di dalamnya dijelskan bahwa salah satu hal penting adalah melakukan pembatasan jumlah orang yang hadir atau petugas dalam kegiatan pemotongan hewan Qurban, antara lain panitia Qurban, petugas pemeriksa kesehatan hewan atau pemilik hewan Qurban. Jumlah panitia Qurban juga dibatasi untuk menghindari kontak fisik serta penyebaran Covid-19. Sebaiknya masyarakat tidak berkumpul menyaksikan pemotongan hewan Qurban, hal ini untuk menghindari kerumunan massa, namun pada kenyataannya masih ada tempat pemotongan hewan Qurban menjadi tontonan yang ramai bagi masyarakat sehingga kepadatan tidak dapat dijaga secara ketat.

Perlunya pembatasan jumlah panitia dan masyarakat dilarang untuk menghadiri kegiatan pemotongan hewan Qurban ini karena penyebaran virus Covid-19 diduga dari orang per orang terutama melalui droplets yang ada di udara pada saat penanganan bahan pangan dan bisa menginfeksi seseorang melalui pernafasan, sehingga menyebabkan demam, batuk, dan sesak nafas sebagai ciri khusus penderita Covid-19 (European Commision, 2020). Resiko partikel virus yang ada dan kontak dengan bahan pangan melalui seseorang yang bekerja sebagai food-handling perlu dilakukan kajian lebih lanjut, sehingga diperlukan adanya penerapan protokol kesehatan di era new normal (IACP, 2020). Hal ini seperti dikemukakan oleh Kresna \& Ahyar (2020) bahwa masyarakat perlu menerapkan protokol kesehatan dalam upaya menjaga penyebaran virus Corona. Kepadatan petugas selama bekerja pada industri daging dan unggas sangat mungkin menyebabkan resiko penularan SARS-CoV-2.

Cara lain yang dilakukan dalam upaya meminimalkan penyebaran Covid-19 adalah dengan kebijakan social distancing yang secara khusus diterapkan pada physical distancing (menjaga jarak) selama kegiatan berlangsung (Government of Ireland, 2020; IACP, 2020, Wei et al., 2020; Pradana \& Casman, 2020). Physical distancing (menjaga jarak) secara drastis mengubah kebiasaan setiap orang dalam bersosialisasi. Physical distancing merupakan salah satu cara untuk meminimalkan penyebaran Covid-19, antara lain dilakukan dengan menjaga jarak antar satu petugas dengan petugas lainnya minimal 1 meter. Hasil memperlihatkan bahwa 69,23\% petugas menerapkan physical distancing dengan pengaturan jarak minimal 1 (satu) meter, dan sisanya yakni 30,77\% belum mampu menerapkan hal tersebut di atas. Hal ini terkait bahwa kegiatan pengulitan, pencacahan, penanganan dan pengemasan daging tidak dilakukan secara berhadapan $(76,92 \%)$ sedangkan 23,08\% masih melakukan kegiatan tersebut secara berhadapan, yang berarti protokol menjaga jarak masih ada yang mengabaikan. 
Pengaturan proses penanganan bahan pangan erat kaitannya dengan kontaminasi produk pangan oleh para pekerja. Penyebaran virus dari satu orang ke orang lain sangat beresiko ketika seseorang bekerja dengan kontak yang sangat dekat antara satu dengan lainnya (European Commision, 2020). Penelitian lebih lanjut oleh Dyal et al., (2020) bahwa praktek secara operasional jarak antar satu petugas dengan petugas lainnya selama bekerja sebaiknya adalah 2 (dua) meter. Aturan tersebut mengacu pada CDC 2020 (Centers for Disease Control and Prevention) yang menjelaskan bahwa untuk membatasi resiko penularan pada proses bahan pangan salah satunya adalah menerapkan prosedur keamanan menjaga jarak yakni 2 (dua) meter antar pekerja. Sehingga perlu adanya modifikasi atau pengubahan pengaturan tata kelola fasilitas pengolahan sehingga aturan tersebut memungkinkan untuk diterapkan. Selain menjaga jarak, memperhatikan waktu untuk bersosialisasi antar petugas, serta mengurangi kontak yang terlalu lama dengan hewan ternak juga menjadi salah satu hal yang perlu diperhatikan.

Sangat penting bagi setiap petugas untuk memiliki alat pemotong sendiri, guna meminimalkan penyebaran Covid-19. Sebanyak 92,31\% petugas membawa peralatan sendiri dan tidak melakukan peminjaman alat, sedangkan sisanya yakni 7,69\% petugas tidak membawa alat sendiri, atau meminjam dari petugas lainnya. FDA menyarankan bahwa semua perlengkapan dan peralatan yang digunakan petugas sebaiknya dicuci sendiri, dipisahkan, dan tidak melakukan peminjaman alat untuk minimalkan penyebaran infeksi virus.

Setelah pengerjaan, petugas diharapkan tetap menjaga kebersihan dengan mencuci peralatan ataupun menyemprot cairan disinfektan sesuai dengan prosedur operasional guna meminimalkan penyebaran virus (Dyal et al., 2020). Hal ini terlihat dari hasil bahwa 100\% petugas melakukan pembersihan tempat pemotongan hewan serta peralatan yang digunakan dan membuang kotoran atau limbah pada fasilitas penanganan kotoran atau limbah. Selanjutnya sebelum kembali ke rumah dan kontak dengan keluarga, petugas juga melakukan pembersihan diri secara mandiri. Dikemukakan oleh Thippareddi (2020) bahwa pembersihan semua peralatan setelah pengoperasian selesai terbagi menjadi beberapa tahap. Yang pertama adalah membersihkan dari bahan-bahan kotor, kemudian mencuci dengan air yakni menggunakan sabun dan bahan lain yang secara fisik dapat menghilangkan korotan, untuk selanjutnya dibilas kembali hingga bersih. Meskipun secara umum kegiatan ini tidak secara efektif berdampak pada keberadaan virusm namun pengaplikasian pembersuhan dengan cleaning agents dapat membuat virus menjadi tidak aktif. Dikemukakan lebih lanjut bahwa pembersihan secara basah (wet cleaning) melibatkan larutan alkali (alkaline based) sebagai pembersih dapat menghilangkan protein dan lemak yang ada, senyawa asam (acid based) juga dapat menghilangkan sisa mineral dan detergen dapat menghilangkan semua kotoran dan tanah yang ada di permukaan.

Pendistribusian daging Qurban sebanyak 84,62\% dilakukan oleh panitia ke rumah mustahik, hal ini guna memperpendek resiko penularan rantai penyebaran Covid-19 serta meminimalkan kontak dengan orang per orang. Namun masih ada pendistribusian yang dilakukan oleh panitia tidak kepada mustahik, namun langsung ke masyarakat sekitar, yakni sebesar 15,38\%. Titik kritis penyebaran Covis-19 dapat terjadi pada tahap ini. Pembagian hewan Qurban adalah salah satu hal yang harus diperhatikan. Hal ini karena Covid-19 dapat tetap ada hingga 24 jam dan beberapa hari pada permukaan pengemas, seperti yang berasal dari bahan karton (untuk pengemas kardus) dan kantong plastik, meskipun tingkat kelembaban dan suhu ikut menjadi faktor pendukung virus berkembang lebih cepat. Penggunakan bahan pengemas dapat memicu resiko penularan Covid-19 oleh petugas yang terkena infeksi (European Commision, 2020). Virus yang ada di kemasan dan tersentuh oleh kulit (dipegang oleh tangan, yang kemudian menyentuh area wajah), maka akan terjadi transfer virus. Sehingga, penanganan pengemasan dan pembagian kepada konsumen sebaiknya tetap mengikuti standar kesehatan Covid-19 tentang praktek sanitasi, antara lain secara 
teratur mencuci tangan atau menggunakan hand sanitizer setelah membagikan daging hasil Qurban, serta konsumen segera mengganti bahan kemasan sendiri setelah diterima. Hasil penelitian pada FERN (2020) yakni pada Juni 2020 kurang lebih 250 daging dalam kemasan dan 86 tanaman pada proses pengolahan yang berasal dari 46 petani dikonfirmasi mengalami kasus Covid-19. Hal ini menjadi contoh bahwa pandemic ini secara signifikan selain berpengaruh pada perekonomian juga sektor pangan dengan resiko pada manajemen pekerja.

Secara umum, 84,62\% petugas mengetahui tentang protokol penyembelihan hewan Qurban di era new normal dan sisanya yakni $15,38 \%$ belum mengetahui. Hal ini terkai dengan sosialisasi yang diadakan oleh Dinas terkait, dan hasil memperlihatkan bahwa 84,62\% petugas pernah mendapat edukasi atau penyuluhan dari dinas tentang tata cara pemotongan hewan Qurban di era New Normal, dan sisanya yakni $15,38 \%$ belum mendapatkan edukasi dari dinas terkait. Adapun Dinas telah melakukan edukasi dan sosialisasi secara online melalui Zoom pada tanggal 15 Juli 2020 dengan tema Kurban yang Aman dan ASUH di Masa Pandemi Covid-19. Kendala yang dihadapi adalah masih banyak takmir masjid yang tidak mengikuti acara sosialisasi tersebut, sehingga informasi belum diterima oleh masyarakat secara luas. Adapun petugas yang mendapatkan informasi terkait tatanan penyembelihan hewan Qurban di era new normal tidak hanya berasal dari pihak Dinas, namun bisa di dapat pada sosial media, antara lain melalui face book, instagram, grup Whatsapp, dan televisi.

\section{KESIMPULAN}

Hasil dari penelitian ini dapat disimpulkan bahwa petugas secara umum mengetahui protokol kesehatan, namun protokol kesehatan belum diterapkan pada saat penyembelihan hewan qurban secara menyeluruh. Edukasi dari dinas terkait memberi pengaruh bagi masyarakat tentang protokol kesehatan selama penyembelihan hewan qurban.

\section{UCAPAN TERIMA KASIH}

Ucapan terima kasih kepada seluruh pihak yang telah membantu penelitian ini. Terima kasih teruntuk para petugas medis yang selalu siaga menghadapi berbagai pasien dan merawat pasien Covid-19, serta seluruh masyarakat yang mampu tetap mempertahankan protokol kesehatan terhadap Covid-19.

\section{DAFTAR PUSTAKA}

ANR - Associação Nacional de Restaurantes. (2020). Especial Coronavírus - 6 abril 2020.Edição 547 - Ano 12. https://anrbrasil.org.br/wp-content/uploads/2020/04/news_547r.pdf

CDC. (2020). Meat and Poultry Processing Workers and Employers. Atlanta, GA:US Department of Health and Human Services, CDC; 2020. https://www.cdc.gov/coronavirus/2019ncov/community/organizations/meatpoultry-processing-workers-employers.html

Cui, J., Li, F., \& Shi, Z. L. (2019). Origin and evolution of pathogenic coronaviruses. Nature Reviews Microbiology, 17(3), 181-192. https://doi.org/10.1038/s41579-018-0118-9.

Decaro, N., \& Lorusso, A. (2020). Novel human coronavirus (SARS-CoV-2): A lesson from animal $\begin{array}{llll}\text { coronaviruses. } & \text { Veterinary } & \text { Microbiology. }\end{array}$ https://doi.org/10.1016/j.vetmic.2020.108693.

Dhama, K., Pawaiya, R. V. S., Chakraborty, S., Tiwari, R., Saminathan, M., \& Verma, A. K. (2014). Coronavirus infection in equines: a review. Asian Journal of Animal and Veterinary Advances, 9(3), 164-176. 
Dhama, K., Sharun, K., Tiwari, R., Sircar, S., Bhat, S., \& Malik, Y. S. (2019). Coronavirus Disease 2019: COVID-19. Clinical Microbiology Reviews, 33(4), Preprints. 2020; https://doi.org/10.20944/preprints202003.0001.v1.

Dyal, J., et al. (2020). Covid-19 among workers in meat and poultry processing facilities 19 states, April 2020. Morbidity and Mortality Weekly Report, 69(18), 557-561.

European Commision. (2020). Covid-19 and Food Safety, Question and Answer. European Commision Directorate General for Health and Food Safety Crisis Management in Food, Animal and Plants.

European Food Safety Authority (EFSA). Coronavirus: no evidence that food is a source or transmission route. https://www.efsa.europa.eu/en/news/coronavirus-no-evidence-food-source-ortransmission-route.

FERN. (2020). Mapping covid-19 outbreaks in the food system / food and environment reporting network. thefern.org/2020/04/mapping-covid-19-in-meat-and-food-processing-plants/.

Government of Ireland. (2020). Return to Work Safely Protocol COVID-19 Specific National Protocol for Employers and Workers. https://dbei.gov.ie/en/Publications/Publication-files/Return-toWork-Safely-Protocol.pdf.

Irish Association for Conselling and Pyscotherapy (IACP). (2020). IACP COVID-19 Return-to-work Guidelines for Members. https://iacp.ie/Covid19-Return-to-work-Guidelines-for-Members\#.

Jayusman. (2012). Tinjauan hukum islam terhadap ibadah kurban kolektif. Al-'Adalah, X(4).

Kresna, A., \& Ahyar, J. (2020). Pengaruh Physical Distancing dan Social Distancing terhadap Kesehatan dalam Pendekatan Linguistik. Jurnal SyntaxTransformation, 1(4), 14-19.

Muhyiddin. (2020). Covid-19, new normal dan perencanaan pembangunan di Indonesia. The Indonesian Journal of Development Planning, IV(2), 240-252.

Mukharom, HA. 2020. Kebijakan Nabi Muhammad SAW menanggapi wabah penyakit menular dan implementasinya dalam konteks menanggunlangi Coronavorus Covid-19. Jurnal Sosial \& Budaya Syar-i FSH UIN Syarif Hidayatullah, 7(3).

Pradana, A. A., \& Casman, C. (2020). Pengaruh Kebijakan Social Distancing pada Wabah COVID-19 terhadap Kelompok Rentan di Indonesia. Jurnal Kebijakan KesehatanIndonesia: JKKI, 9(2), 6167.

Randazzo, W., Truchado, P., Cuevas-Ferrando, E., Simon, ' P., Allende, A., \& Sanchez, ' G. (2020). SARSCoV-2 RNA in wastewater anticipated COVID-19 occurrence in a low prevalence area. Water Research, Article 115942. https://doi.org/10.1016/j.watres.2020.115942.

Sabiq, S. (1983). Fiqih Al Sunnah. Bayrut: Dar Al-Fikr.

Shaw, K. A., Szablewski, C. M., Kellner, S., Kornegay, L., Bair, P., Brennan, S., ... \& Kobayashi, M. (2019). Psittacosis outbreak among workers at chicken slaughter plants, Virginia and Georgia, USA, 2018. Emerging Infectious Diseases, 25(11), 2143.

Syafii, A. (2019). Tiga Miliar Muslim Tahun 2060: Berita Gembira atau Bencana? https://republika.co.id/berita/q03z7x440/tiga-miliar-muslim-tahun-2060-berita-gembiraatau-bencana.

Su, S., Wong, G., Shi, W., Liu, J., Lai, A. C. K., Zhou, J., Liu, W., Bi, Y., \& Gao, G. F. (2016). Epidemiology, genetic recombination, and pathogenesis of coronaviruses. Trends in Microbiology, 24(6), 490502. https://doi.org/10.1016/j.tim.2016.03.003.

Thippareddi, H., Balamurugan, S., Patel, J., Singh, M., \& Brassard, J. (2020). Coronaviruses-Potential human threat from foodborne transmission? LWT, 110147.

Tribunnewsmaker. (2020). DKI Jakarta Bertambah 1.380 Kasus Update Corona Nasional. https://newsmaker.tribunnews.com/2020/09/14/dki-jakarta-bertambah-1380-kasusupdate-corona-nasional-senin-14-september-2020-total-218382.

Wei, W. E., Li, Z., Chiew, C. J., Yong, S. E., Toh, M. P., \& Lee, V. J. (2020). Presymptomatic Transmission of SARS-CoV-2-Singapore, January 23-March 16, 2020. Morbidity and Mortality Weekly Report, 69(14), 411.

World Health Organization (WHO). (2020). Technical interim guidance for novel coronavirus. https://www.who.int/health-topics/coronavirus.

Yuan, J., Lu, Y., Cao, X., \& Cui, H. (2020). Regulating wildlife conservation and food safety to prevent human exposure to novel virus. Ecosystem Health and Sustainability, 6(1), 1741325. 